\title{
METRONIDAZOLE GEL EFFECT ON RATS WITH BACTERIA-INDUCED PERIODONTITIS
}

\author{
Muhamat Muhtar S. Abdurrohman*, Rama Putranto**
}

*Departemen Biologi Oral, Fakultas Kedokteran Gigi, Universitas Islam Sultan Agung Semarang

**Departemen Ortodonsia, Fakultas Kedokteran Gigi, Universitas Islam Sultan Agung Semarang

Correspondence : Muhamat Muhtar S. Abdurrohman, Departemen Biologi Oral, Fakultas Kedokteran Gigi, Universitas Islam Sultan

Agung Semarang

Email : m.muhtar@unissula.ac.id

\section{Keywords: \\ Metronidazole gel, \\ Peridontitis, \\ TIMP-1 Levels}

\begin{abstract}
Background: Periodontitis is an inflammatory disease in the periodontal tissue and causes progressive tissue damage. Tissue Inhibitor of Matrix Metalloproteinases-1 (TIMP-1) is directly responsible for the pathogenesis of periodontal diseases. Topical application of the metronidazole gel as a therapy for periodontal diseases can be used for additional therapy. This study aimed to analyze the effect of Metronidazole gel on periodontitis based on TIMP-1 levels in bacteria-induced periodontitis in rats.

Methods: Twenty Sprague Dawley rats weighing 170-200 gram aged two months. Rats were divided into two groups: the control group and Metronidazole gel (Ti-es Metronidazole gel, $0.45 \mathrm{mg}$ ). Metronidazole gel was topically applied to the gingival sulcus. The gingival crevicular fluid sample was taken on day 3 with periopaper subjected to the Tissue Inhibitor of Matrix Metalloproteinase-1 level evaluation using the ELISA Method.

Results: Normal reference Tissue Inhibitor of Matrix Metalloproteinase 1 levels gingival crevicular fluid $0.156-10 \mathrm{ng} / \mathrm{ml}$. Tissue Inhibitor of Matrix Metalloproteinase 1 gingiva crevicular fluid in control and metronidazole gel was $1.34 \mathrm{ng} / \mathrm{ml}$ and $3.57 \mathrm{ng} / \mathrm{ml}$. There was a significant difference between control and metronidazole gel group $(p<0.005)$

Conclusion: The Application of Metronidazole gel affects TIMP-1 levels in periodontitis.
\end{abstract}

\section{PENDAHULUAN}

Periodontitis merupakan inflamasi jaringan periodontal yang ditandai dengan kehilangan perlekatan dan kerusakan tulang alveolar. ${ }^{1}$ Bakteri utama penyebab periodontitis diantaranya bakteri Gram negatif seperti Agregatinobacter actinomycetemcommitans, Porphyromonas gingivalis dan Provotella intermedia. ${ }^{2}$ Mikroorganisme dan produknya merupakan etiologi utama menginisiasi kerusakan jaringan periodontal secara langsung, namun kerusakan utama jaringan periodontal disebabkan oleh derivat enzim proteolitik pejamu. $^{3}$

Tissue inhibitor of Matrix Metalloproteinase 1 (TIMP-1) merupakan inhibitor enzim proteolitik matrik ekstraseluler yaitu Matrix Metalloproteinase (MMP). MMP berperan secara pathogen pada kasus penyakit periodontal. ${ }^{4}$ Peningkatan Kadar TIMP-1 pada cairan sulkus gingiva menunjukkan mekanisme kerja TIMP sebagai inhibitor dan peran dalam regulasi MMP. Kondisi tersebut dapat diamati pada periodontitis yang mendapatkan terapi. $^{3}$

Beberapa pendekatan terapi periodontitis bertujuan untuk reduksi dan eradikasi periodontal pathogen yang spesifik. Pendekatan tersebut dengan pemberian antibiotik lokal dan sistemik. Penggunaan antibiotik secara sistemik mempunyai efek seperti resistensi antibiotik dan reaksi obat yang tidak diinginkan seperti nausea, kolitis 
pseudomembran dan diare.5.6 Berdasar hasil pertimbangan tersebut pemberian terapi antibiotik secara lokal dengan Metronidazole gel pada poket periodontal memberikan kemajuan perawatan. Selain terapi langsung pada tempat target, dapat meminimalisir efek samping secara sistemik. ${ }^{7}$

Berdasar kajian ilmiah tersebut maka tujuan dari penelitian ini dapat mengevaluasi efek Ties Metronidazole Gel pada Tikus dengan Periodontitis yang diinduksi bakteri dengan melihat parameter kadar Tissue inhibitor of Matrix Metalloproteinase 1 (TIMP-1).

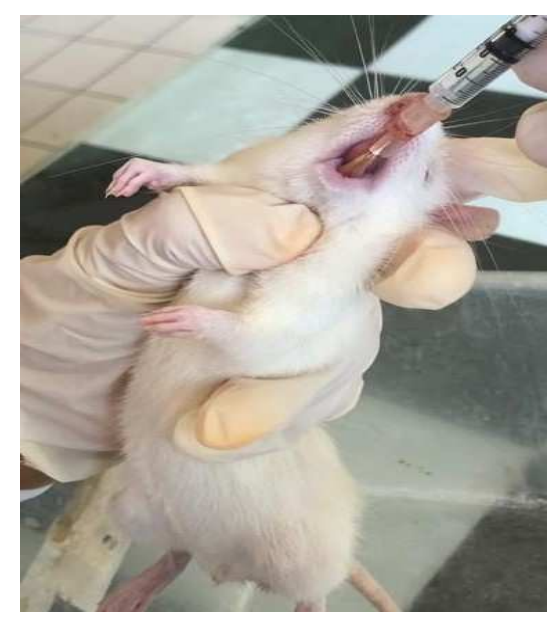

Gambar 1. Aspek makroskopis induksi Periodontitis dengan Agregatinobacter

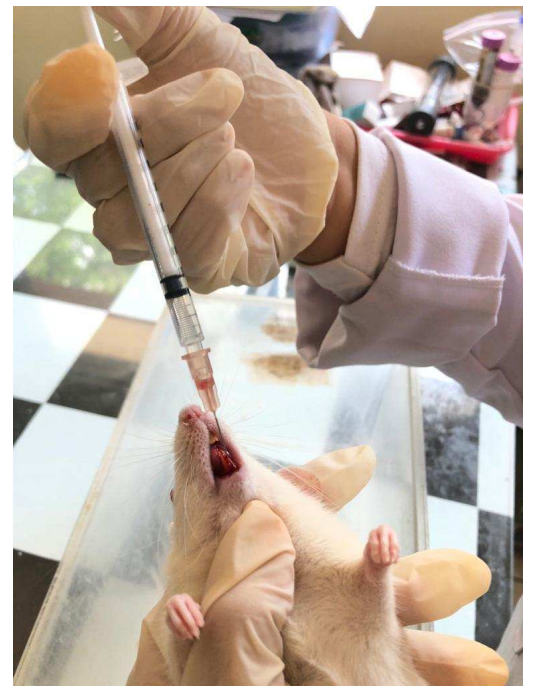

Gambar 2. Aspek makroskopik aplikasi Metronidazole gel intrasulkuler gigi depan rahang bawah hari ke-1

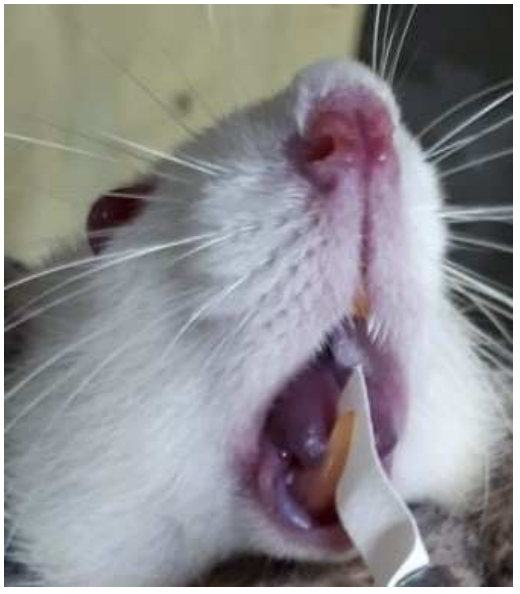

Gambar 3. Aspek makroskopis pengambilan cairan sulkus gingiva menggunakan paper strip pada hari ke-3

\section{METODE PENELITIAN}

Ethical clearance penelitian ini dari Komisi Bioetika Kedokteran/Kesehatan Fakultas Kedokteran Unissula No.48/II/2018/Komisi Bioetik.

Penelitian ini adalah true eksperimental dengan pengambilan sampel secara random. Hewan coba yang digunakan pada penelitian ini adalah 20 tikus jantan Sprague dawley dengan berat 170-200 gram dan berusia 2 bulan. Semua Tikus dianestesi injeksi ketamine $\mathrm{HCl}$ secara intramuskular pada otot paha belakang dengan dosis $0,2 \mathrm{ml} / 200 \mathrm{gram} \mathrm{BB.}{ }^{2}$ Induksi periodontitis dilakukan dengan diinfeksikan suspensi bakteri Agregatinobacter Actinomycetemcomitans per injeksi melalui sulkus gingiva (intrasulkuler) sekeliling gigi incisivus anterior rahang bawah tikus. Kriteria periodontitis pada sampel yaitu adanya poket periodontal, probing deep (PD) lebih dari 3 $\mathrm{mm}$ dan resesi gingiva. ${ }^{8}$

Pada hari ke-7 tikus kemudian dibagi menjadi dua kelompok yaitu kontrol dan perlakuan. Pemberian perlakuan berupa aplikasi Ti-es Metronidazole gel dengan memasukkan ujung tip jarum tumpul kedalam poket sedalam $2 \mathrm{~mm}$ lalu diaplikasikan sampai terlihat ada gel keluar dari marginal gingiva dan ekses dibersihkan dengan 
cotton. Aplikasi tersebut dilakukan sekali pada hari 1 perlakuan. $^{9}$

Pada hari ke-3 setelah perlakuan tikus dianestesi dengan senyawa eter dan dilakukan pengambilan cairan sulkus gingiva. ${ }^{10}$ Pengambilan cairan sulkus gingiva dilakukan dengan paper strip yang dimasukkan pada sulkus gingiva. Lebar paper strip $1,5 \mathrm{~mm}$ dan dimasukkan $1 \mathrm{~mm}$ ke dalam sulkus, kemudian cairan sulkus gingiva akan terserap pada paper strip dan dimasukkan ke tabung Eppendorf yang telah berisi larutan buffer PBS sebanyak 100 $\mu$ L. ${ }^{11.12}$ Sampel disimpan pada suhu $-20^{\circ} \mathrm{C}$ sampai jumlah sampel mencukupi. Pembacaan kadar Tissue inhibitor of Matrix metalloproteinase 1 menggunakan metode ELISA dengan absorbansi $450 \mathrm{~nm} .^{13}$

Analisis data meliputi uji normalitas menggunakan uji Shapiro-Wilk dan homogenitas menggunakan uji levene statistic dilanjutkan dengan uji One Way ANOVA untuk melihat signifikansi.

\section{HASIL PENELITIAN}

Hasil penelitian menunjukkan peningkatan rerata kadar TIMP-1 pada semua kelompok perlakuan Ti-es Metronidazole gel (Tabel.1)

Tabel 1. Rerata kadar TIMP-1

\begin{tabular}{lll}
\hline & \multicolumn{1}{l}{ Kelompok } & \\
\cline { 2 - 3 } Variabel & Kontrol & Perlakuan \\
\cline { 2 - 3 } & Hari ke-3 & Hari ke-3 \\
\cline { 2 - 3 } & $\mathrm{N}=10$ & $\mathrm{~N}=10$ \\
\cline { 2 - 3 } & $\mathrm{X}( \pm \mathrm{SD})$ & $3.57( \pm 2.35)$ \\
\hline $\begin{array}{l}\text { Kadar TIMP-1 } \\
\text { (ng/ml) }\end{array}$ & $1.34( \pm 0.00)$ & \\
& &
\end{tabular}

Hasil uji normalitas Shapiro-wilk menghasilkan data terdistribusi tidak normal ( $p<0.05), \quad p=0.00$ baik pada kelompok kontrol maupun perlakuan. Uji homogenitas menggunakan uji Levene test hasilnya adalah $p<0.05$, menunjukkan data homogen. Uji selanjutnya dengan Mann Whitney. Uji Mann-Whitney kelompok kontrol nilai $p=0.00(p<0.05)$ sedangkan pada kelompok perlakuan dengan metronidazole gel nilai $p=0.00 \quad(p<0.05)$ sehingga terdapat perbedaan yang bermakna kadar TIMP-1

\section{DISKUSI}

Pada penelitian ini dilakukan induksi periodontitis pada tikus dengan tanda klinis periodontitis tampak warna margin gingiva kemerahan, probing deep (PD) 3-4 mm, kontur margin gingiva yang membulat dan terjadi penurunan margin gingiva (resesi gingiva). ${ }^{2}$ Mekanisme yang mungkin mendasari pada kondisi periodontitis tersebut adanya degradasi matrik ekstraseluler periodontal dan protein bakteri. ${ }^{14}$

Kerusakan jaringan periodontal dimediasi secara signifikan oleh kadar MMP. Regulasi MMP dikendalikan oleh TIMP dengan menghambat enzim proteinase dan memblok aktivasi MMP secara autokatalitik. ${ }^{15.16}$ Beberapa sinyal molekul seperti sitokin, kemokin, Growth factor diaktivasi oleh MMP. Sitokin adalah modulator kunci respons seluler selama peradangan periodontal dan setelah berikatan dengan reseptor dalam sel target, maka akan menginduksi sinyak intraseluler dan memodifikasi ekspresi gen. Demikian juga, kemokin merupakan molekul kecil yang bertanggung jawab pada sinyal peradangan dan bersifat spesifik. ${ }^{17}$ Keseimbangan sitokin dan kemokin berhubungan dengan perkembangan periodontitis, mencakup durasi, intensitas dan respon jaringan. Sekresi sitokin Th1 proinflamatori secara persisten pada jaringan periodontal, seperti tumor necrosis factor alpha (TNF), interleukin (IL-1, IL-6, IL-12, dan interferon gamma, Th17 sitokin, seperti interleukin IL-17, bersama dengan kadar sitokin regulatori (Treg) yang rendah, seperti IL-10, dan mentransformasikan growth factor beta 1 
(TGF-1), berhubungan dengan peradangan dan kerusakan jaringan periodontal. ${ }^{17}$

Semakin parah peradangan jaringan periodontal, semakin tinggi konsentrasi MMP aktif. Pada cairan sulkus gingiva dan gingiva, MMP-1, -2, -3 , dan -9 meningkat secara signifikan, sedangkan TIMP-1 dan -2 menurun secara signifikan. Penghambatan ekspresi atau aktivitas MMP, atau peningkatan ekspresi TIMP, dapat mengurangi kerusakan jaringan periodontal. ${ }^{18}$

TIMP mengendalikan aktivitas matrix metalloproteinase pada periseluler, sedangkan Alpha 2-macroglobulin berfungsi sebagai pengatur cairan tubuh. ${ }^{18}$ Beberapa penjelasan peningkatan kadar TIMP-1 setelah pemberian antibiotik pada penyakit periodontal: (1) Penurunan kadar MMP oleh karena adanya TIMP sebagai inhibitor; namun regulasi TIMP-1 mungkin tidak semata-mata bergantung pada MMP, (2) Penurunan kadar TIMP-1 pada subjek yang mengalami periodontitis bisa disebabkan oleh degradasi selektif TIMP-1 oleh neutrofil elastase atau inaktivasi TIMP-1 oleh neutrofil sendiri setelah pelepasan oksidan, (3) Peningkatan level TIMP-1 dapat mencerminkan keterlibatannya dalam proses penyembuhan, (4) mekanisme yang tidak teridentifikasi untuk kontrol kadar MMP dengan TIMP-1. ${ }^{15}$

Hasil penelitian menunjukkan pemberian antibiotik Metronidazole gel dapat menaikkan kadar Tissue inhibitor of Matrix metalloproteinase-1 pada periodontitis. Penelitian yang mendukung efek antibiotik mampu membantu preservasi jaringan periodontal adalah Ravi P. Popat dkk (2014). ${ }^{19}$

Metronidazole gel secara khusus bersifat bakterisidal terhadap mikroorganisme anaerob, yang dikenal sebagai patogen utama terkait periodontitis sehingga metronidazole gel dapat diaplikasikan pada periodontitis kronis. Secara sistematis antibiotik kurang efektif terhadap biofilm apabila penetrasi biofilm terhadap antibiotik inadekuat. Sehingga penentuan antibiotik disesuaikan terhadap mikroorganisme subgingiva dan respon yang diharapkan meningkatkan penyembuhan. ${ }^{20}$

Penelitian ini menggunakan ELISA untuk menentukan kadar TIMP-1 pada cairan sulkus gingiva, dengan mengukur tingkat total enzim (baik aktif dan laten) dalam GCF daripada tingkat enzim aktif. Meskipun jumlah proporsional enzim aktif bisa rendah setelah perawatan. Dengan demikian, disarankan penelitian selanjutnya untuk melakukan studi yang dapat membedakan kadar TIMP-1 antara bentuk aktif dan laten (tidak aktif). Pengembangan penelitian kadar TIMP-1 pada jaringan periodontal dan biomarker lain yang dapat diamati melalui cairan sulkus gingiva diperlukan, untuk memantau uji diagnostik dan imunologis periodontitis dalam perawatan.

\section{KESIMPULAN}

Metronidazole gel berefek pada tikus periodontitis yang diinduksi bakteri dengan melihat kadar TIMP-1. Kadar TIMP-1 meningkat setelah pemberian Metronidazole gel. Hal ini menunjukkan peran penting antibiotik lokal yaitu Metronidazole gel pada perawatan periodontitis.

\section{UCAPAN TERIMAKASIH}

Dengan selesainya penelitian ini, kami mengucapkan terima kasih kepada Dekan FKG Unissula, LPPM Unissula, Lab PAU Gadjah Mada yang telah memberikan support dalam pelaksanaan penelitian ini.

\section{DAFTAR PUSTAKA}

1. Hafez Mohd F, Al Bayaty Fouad H, Ihsan AM. Prevalence and Evaluation of Bone Loss Pattern among Patient with Aggressive Periodontitis. J Int Dent Med Res. 2017;10(3):862-867.

2. Prasetya RC, Purwanti N, Haniastuti T. Infiltrasi Neutrofil pada Tikus dengan Periodontitis 
setelah Pemberian Ekstrak Etanolik Kulit Manggis. Maj Kedokt Gigi Indones. 2014;21(1):33.

DOI:10.22146/majkedgiind.8520.

3. Balli U, Cetinkaya BO, Keles GC, et al. Assessment of MMP-1, MMP-8 and TIMP-2 in experimental periodontitis treated with kaempferol. J Periodontal Implant Sci. 2016;46(2):84-95.

DOI:10.5051/jpis.2016.46.2.84.

4. Barros SP, Williams R, Offenbacher S, Morelli T. Gingival crevicular fluid as a source of biomarkers for periodontitis. Periodontol 2000. 2016;70(1):53-64. DOI:10.1111/prd.12107.

5. Athraa Ali Mahmood, Ghasaq A. Abdul-Wahab SIA-K. Effect of Hyaluronan and Metronidazole Gels in Management of Chronic Periodontitis. J Int Oral Heal. 2020;11(June):158-163. DOI:10.4103/jioh.jioh.

6. Ansari SA, Syed SA, Quadir F, Aslam K. Effect of $1 \%$ Metronidazole $\mathrm{Gel}$ as an Adjunct to Subgingival Scaling in the Treatment of Periodontitis. J Pakistan Dent Assoc. 2017;26(3):123-128.

DOI:10.25301/jpda.261.123.

7. Rajagopalan A, Thomas DJT. Effectiveness of Metronidazole as Local Drug Delivery in Periodontal Diseases - A Review. IOSR J Dent Med Sci. 2014;13(8):25-28. DOI:10.9790/085313842528.

8. Minic I, Pejcic A. Pathogenesis of Aggregatibacter actinomycetemcomitans in Periodontitis. 2019;(March).

9. Miani PK, Do Nascimento C, Sato S, Filho A V., $\mathrm{Da}$ Fonseca MJV, Pedrazzi V. in vivo evaluation of a metronidazole-containing gel for the adjuvant treatment of chronic periodontitis: preliminary results. Eur J Clin Microbiol Infect Dis. 2012; 31(7): 1611-1618. DOI:10.1007/s10096-011-1484-7.

10. Reddy NR, Deepa A, Babu DSM, Chandra NS, Reddy CVS, Kumar AK. Estimation of tissue inhibitor of matrix metalloproteinase-1 levels in gingival crevicular fluid in periodontal health, disease and after treatment. J Indian Soc Periodontol. 2014;18(3):301-305. DOI:10.4103/0972-124X.134565.

11. Matsuda S, Movila A, Suzuki M, et al. A novel method of sampling gingival crevicular fluid from a mouse model of periodontitis. 2016:438:21-25.

DOI:10.1016/j.jim.2016.08.008.
12. Taylor JJ. Protein Biomarkers of Periodontitis in Saliva. ISRN Inflamm. 2014;2014(Cvd):1-18. doi:10.1155/2014/593151.

13. Majeed ZN, Philip K, Alabsi AM, Pushparajan $S$, Swaminathan D. Identification of Gingival Crevicular Fluid Sampling , Analytical Methods , and Oral Biomarkers for the Diagnosis and Monitoring of Periodontal Diseases: A Systematic Review. 2016;2016.

14. Gulnur Erningil, Buket Han, Ali Gurkan, Afig Berdeli, Taina Tervahartiala E. Matrix Metalloproteinase ( MMP ) -8 and Tissue Inhibitor of MMP-1 ( TIMP-1 ) Gene Polymorphisms in Generalized Aggressive Periodontitis : Gingival Crevicular Fluid MMP-8 and TIMP-1 Levels and Outcome of Periodontal Therapy. J Periodontal. 2015;85(November 2013):1070-1080.

DOI:10.1902/jop.2013.130365.

15. Popat RP, Bhavsar N V, Popat PR. Gingival crevicular fluid levels of Matrix Metalloproteinase-1 ( MMP-1) and Tissue Inhibitor of Metalloproteinase-1 ( TIMP-1) in periodontal health and disease. Singapore Dent $\mathrm{J}$. 2014;35:59-64. DOI:10.1016/j.sdj.2014.07.003.

16. Prado P, Rossy B, Molina B, Prado P, Rossy B. Metalloproteinases (MMPs) of the extracellular matrix in Dentistry. XVIII(November 2016):1928.

17. Franco C, Patricia HR, Timo S, Claudia B, Marcela H. Matrix metalloproteinases as regulators of periodontal inflammation. Int $\mathrm{J} \mathrm{Mol}$ Sci. 2017;18(2):1-12. DOI:10.3390/ijms 18020440.

18. 18. KJ N. Role of Matrixmetalloproteinases in Periodontal Disease - A Review. Biomed J Sci Tech Res. 2018;2(1):2099-2104. DOI:10.26717/bjstr.2017.01.000632.

19. Botelho MA, Martins JG, Ruela RS, Queiroz DB. Nanotechnology in ligature-induced periodontitis : protective effect of a doxycycline gel with nanoparticules. 2010;18(4):335-342.

20. Rosamma G, Kavyashree G. Effect of hyaluronan and Metronidazole gels in management of chronic periodontitis. J Int Oral Heal. $\quad 2019 ; 11$ (November):158-163. DOI:10.4103/jioh.jioh. 